solutions is changed. Developing this in a concluding address, Prof. E. K. Rideal observed that the fibrils would presumably behave as supermolecules and that the ratio of crystalline to amorphous regions, which is of much importance with polymers, would probably have a large influence on the properties of set cement. In the dehydration of zeolites, water can be removed without altering the external appearance, but holes may be left in the structure which would admit molecules of hydrocarbons. More information is needed about energy changes in such processes. Some alumino-silicates have a disk-like structure, and up to four layers of water molecules can be adsorbed between each disk. The system remains ordered if water is removed slowly, but on quick drying a disordered state may result. For an ordered system, the expansion on wetting is lateral for a water-rich system, and perpendicular for a water-poor system. The transportation of silt within a cement mass may also be of importance. Prof. Rideal referred in addition to work on diffusion gradients at crystal edges and the existence of mobile layers at crystal boundaries. It is possible that re-arrangement in a cement-water system may take place by osmosis, by transportation of silt, or by molecular movements.

F. M. L.

\section{ANTHROPOLOGY ON THE CONTINENT OF EUROPE IN WAR-TIME}

A $\mathrm{S}$ has already been reported in Nature of May 18, p. 665, the Permanent Council of the International Congress of Anthropological and Ethnological Sciences visited England during April at the invitation of the Roy Anthropological Institute, and a most successfery thing was organised at Oxford by Sir Johromyres $g^{2}$ of the joint secretaries of the Conghs, to maks arrangements for the next full meeting and to adighe the work of the standing committees. The Roy Anthropological Institute took advantage of this gathering to invite the delegates to read short papers at informal meetings of the Institute in London, on the days immediately preceding and following the Oxford meetings, as a means of making better known in Britain and among the delegates themselves the progress made in anthropological science in their several countries since the outbreak of war brought international contacts to a stop. Eleven of the delegates accepted this invitation, and in addition two of the delegates delivered during their visits the Huxley Memorial Lectures for 1941 and 1945.

Mention should first be made of a full and illustrated account, given by Miss Johanna Felhoen Kraal (one of the Netherlands delegates) at an ordinary meeting on April 2, of the work of the Ethnographical Section of the Netherlands Institute for the Indies at Amsterdam, and particularly of the development of its policy in recent years under the late Prof. B. J. O. Schrieke, whose death in 1945 was so grievous a loss to Holland, to the East Indies and to anthropological science.

At the first of the special meetings, held on April 11, Prof. J. M. de Barandiaràn, who attended as a delegate of France, gave an illuminating account of Basque studies during the past ten years, mainly under the auspices of the Basque Research Institute, founded in 1921, which publishes the Anuario de Etnologia and the monthly Eusko-Folklore. The outbreak of the Spanish Civil War interrupted a number of important excavations at prehistoric sites in Spain which had already thrown much light on the origins of the Basque type so far back as the upper Palæolithic. Since 1937, the Institute's work had been confined to the French side of the frontier, and was on a reduced scale, though Prof. Barandiaràn had himself made some important discoveries suggesting a correlation between the distribution of ancient dolmens and cromlechs and the nomadism still practised in the same areas. Ethnographical work included studies of current folk-lore which seemed to have prehistoric parallels.

Prof. Edouard de Jonghe (Brussels) gave a very full and authoritative account of war-time progress in anthropological knowledge of the Belgian Congo. Most of the Belgian universities, museums, learned societies and scientific publications carried on through. out the German occupation, generally on a reduced scale, and resisted German influence with success: there were practically no cases of 'collaboration' among anthropologists. Prof. de Jonghe himself was deported to Germany just before the arrival of the Allies in Belgium in 1944. The four years isolation of the metropolis from its colony naturally concentrated the energies of research workers in Belgium upon the working up of material already collected. In the Congo, on the other hand, the War saw a great expansion of anthropological research, especially in the applied field. Prof. de Jonghe's detailed account of work published during the War included, under the head of prehistory, works by Lobar and de Jonghe (in collaboration), Bertrand, Van der Kerken, Bequaert (on the prehistoric collections of the Tervueren Museum), Cabus, Van Moorsel and Mortelmans.

On the physical side, interesting and important work was done on the practical problems of health and demography; but in the special case of the pygmies much fundamental research was also carried out-by Father Schebesta, with his associates Jadin and Gusinde, on the Bambuti pygmies (including blood-group studies); by Jullien, on the blood-groups of the Efe pygmies; by Father Schumacher, in a monumental work to appear shortly, on the Lake Kivu pygmies; and by Twisselmans on the pygmies of West Africa, especially the French Congo. In the linguistic field, a vocabulary of Alur was compiled by Father Van Neste, and a grammar of Chiluba by Father Willems. The use of Chiluba as the national tongue of the whole Belgian Congo had long been advocated by Prof. de Jonghe, and an important session of the Institut Royal Colonial Belge was devoted to discussion of this problem in 1944. A preliminary essay in the application of linguistic geography to the Bantu languages was made by Father de Boeck.

Among general ethnological works was De Cleene's excellent "Introduction à l'Ethnographie du Congo" (written from a rather functional point of view), and important monographs were produced on the Mongo, Basongo and Bakongo by Van der Kerken, de Beaucorps and Mertens. News was also given of the Institute's great investigation of the forms of slavery in the Congo. Juridical ethnology made great strides in the Congo during the War under the influence of Sohier, as had the systematic study of Congo art in Belgium under that of Prof. F. M. Olbrechts. After a short reference to recent studies by Van Reeth, Smets and others in the religions of the Congo and Ruanda, Prof. de Jonghe concluded with an interest- 
ing account of recent studies of African mentality and philosophy by $\mathrm{D}_{\Theta}$ Cleene (following Levy-Brïhl) and Father Tempels. This lecture was a remarkable testimony to the success with which Belgian science has surmounted its war-time difficulties.

Prof. Olbrechts followed with a masterly exposiiton of the scientific approach to the study of Congo art which he has done so much to develop in recent years, distinguishing in the space of an hour, with a large number of excellent illustrations, all the important regional styles, together with the characteristic features by which they may each be identified. The extraordinary variety of styles, nearly all represented by examples of great vigour and high artistic merit, must have convinced all his hearers that the Congo is as fruitful a field for the student of art as any place in the world, and his forthcoming book on the subject will be awaited with great interest. He distinguishes three main zones: the western, which includes the rather decadent and lifeless art of the Lower Congo tribes, so long subject to European contacts, as well as the more southerly Bajokwe, with their far more vigorous and elaborate forms, and the Bapende, whose initiation masks are so arrestingly evocative of death; the central zone, in which are found the Bushongo, whose 'Court style' produced the superb portrait statue of the early seventeenth century Great Chief Shamba Bolongongo-now on view at the British Museum-and the nearby Bena Lulua, with their utterly different but equally fine sculpture; and the eastern zone, where the Baluba are pre-eminent. Particularly interesting among the Baluba figures is a series of half a dozen or more sculptures, now scattered among the museums of Europe, which are so precisely alike in feeling and in many details of style that Prof. Olbrechts believes them to be all from the same master hand. The successful synthesis of the ethnological and resthetic approaches developed in this lecture may be thought highly suggestive for many other regions of the world.

On their return from Oxford on April 16, the delegates were honoured at a reception and lunch by the president and fellows of the Royal Anthropological Institute, after which they visited the British Museum for a special preview of the ethnographical section of the exhibition due to be opened a few days later. After tea with the Folklore Society, they attended the delivery of the Huxley Memorial Lecture, postponed from 1941, by the Abbé Breuil on "La Découverte de l'Antiquité de l'Homme et quelquesunes de ses Evidences", at a special meeting of the Institute in University College. In his memorable address, the Abbe Breuil first surveyed the growth and present state of man's knowledge of his early past, as it had been revealed by geological and archæological evidence, and then gave an account of his war-time field researches, bearing on this subject, on the sea beaches of Morocco, Portugal and South Africa, which has produced some significant correlations. He suggested the possibility that the South African Old Stone Age cultures may actually have been the ancestors of the comparable cultures of Western Europe, Asia Minor and India.

On April 16, the Rev. Pater W. Schmidt gave a short account of some of the effects of war upon anthropological study in the countries with which he has been specially associated-Switzerland and Austria and in particular gave news of the wellknown periodical Anthropos, of which he was the editor; its publication was transferred before the War from Vienna to Fribourg in Switzerland, and for various reasons is likely to remain there for some time to come. In spite of much war damage in Austria, the Natural History Museum at Vienna remains intact. After referring to the Pontificio Museo Missionario-Etnologico Lateranense at the Vatican, of which he is head, he concluded with an appeal for toleration by belligerent governments of the missionaries on whom native peoples depend for guidance, except where individual missionaries are clearly guilty of subversive activity. The wholesale internment, on grounds of nationality, of German and Italian missionaries by the Allies and of European missionaries by the Japanese produced serious ill-effects. He was glad to welcome a more liberal policy in the recent British decision to re-admit the German missionaries in India, Australia and New Guinea.

Prof. Gerhard Lindblom reported that scientific research in Sweden had been relatively little affected by the War. $\mathrm{H}_{\theta}$ surveyed shortly the work and publications of Sweden's famous museums : the Ethnographical Museum of Sweden at Stockholm, under his own direction ; the Ethnographical Museum at Gothenburg, where Izikowitz has succeeded Koudern; the Museum of Far Eastern Antiquities at Stockholm, under Karlgren; the Northern Museum at Stockholm, with its very active Lapp Department under Ernst Manker; and the State Historical Museum at Stockholm, rehoused in 1943, until lately under Arne's direction. On the teaching side, while interest in physical anthropology as such is still in its early stages, the study of general ethnology (now including more social anthropology) and of archæology is very well established in Sweden and has received further notable recognition during the past seven years; and Nordic ethnology is in a particularly flourishing condition, with important researches proceeding under Erixon, Svensson, Campbell and others. The most significant impression to be gained by a British audience from this admirable account was that of the very close and obviously successful interconnexion of the work of the museums and the universities in Sweden, with Lindblom, Karlgren, Izikowitz, Svensson, Lagercrantz and others dividing their energies between the two and helping to foster that integration of ethnological studies which has provided a firm basis for the expansion of activity and of public interest in those studies.

The first of three papers given on the evening of April 17 was by Prof. H. V. Vallois, who reported on the condition of physical anthropology in France during the war years under the three heads of the modern population of France, the coloured races of the French Empire, and fossil man. Systematic field-work in Brittany, the central massif, the Pays Basque and the north of France included an investigation of blood-group distribution which brought to light important regional differences, correlated with morphological characters. Other researches dealt with the Armenians and the Negroes resident in France, and a good deal of material gathered in Africa before the War was worked up and published. Studies of prehistoric remains included those of the Mesolithic men of Deventer (Pays-Bas) and le Cuzoul de Gramat (Département du Lot) and of the Neanderthal man of Rabat in Morocco. Prof. Vallois men. tioned that the progress made in ethnology and prehistory was equally impressive, in spite of the very difficult working conditions for French science and the unwelcome attentions of the German police. 
The address by Prof. G. H. Rivière, keeper of the Musée National des Arts et Traditions Populaires in Paris, on war-time research in the ethnography of France, should be well pondered, not without mortification, in Great Britain, where, but for the pioneer work of Dr. Peate in Wales, we have little indeed to set beside French achievements of recent years. A determined effort is being made by the French museums service, now under the control of the Ministry of Education, to record systematically the fast disappearing 'popular arts' of the country: the principal investigations undertaken during the War covered domestic furniture, rural architecture (for the purposes of reconstruction) and artisan techniques (including pottery, metallurgy, weaving, woodworking and basketry). Specimen files shown by Prof. Rivière for each of these researches gave a striking impression of the thoroughness, completeness and systematic efficiency without which such nationwide investigations could scarcely be successfully undertaken. Lesser researches related to marionette theatres, folk-songs of Brittany, folk-tales, and to preparations for an ethnographical atlas of France and ethnographical monographs on particular French communities studied from all aspects. In 1945, the 557 provincial museums concerned with French ethnography were reorganised under a master plan providing for the division of their collections into carefully selected and well-spaced temporary exhibitions and larger reserve collections for scientific study. It may be hoped that full accounts of these developments will soon be available in Britain, for, without necessarily accepting so high a degree of centralization, we may gain much inspiration from French experience.

Prof. Sergio Sergi, of Rome, gave a short report, illustrated with photographs and diagrams, on the very important discoveries of human remains of Palæolithic age which he made at Saccopastore and Monte Circeio during the War, together with comparisons of the crania with those of other known specimens of Palæolithic man.

In physical anthropology, as in domestic ethnography, Great Britain lags at present far behind, and Prof. Tamagnini's talk on April 18, outlining remarkable progress made in Portugal, was fresh and salutary proof of this. After a short sketch of the history of anthropological studies in Portugal (with their emphasis from the beginning on the physical side), he summarized current research activities at Lisbon (under Heleno, de Vilhena and Barbosa Sueiro), Porto (Mendes Corrêa and Pires de Lima) and Coimbra (the speaker himself and Serra). Finally, he described his own Institute's very large and important statistical undertaking, in which the genealogical method is being applied to the study of blood groups and other characters among great numbers of families in the Department of Coimbra.

Prof. Valšik of Prague gave a very brief statement of the effect of German occupation upon Czechoslovak anthropology. All organised research in science had stopped, in default of any subservience to the Germans, and no publication had been possible. Physical anthropologists, such as himself, had mostly been engaged on the applications of science to health.

Lastly, Prof. Shevket Aziz Kansu's short but informative review of recent progress in Turkey showed that he and his colleagues were extremely active during the War, and that all branches of the science were being very successfully developed there.
On April 30, Prof. A. L. Kroeber, the United States delegate, delivered the Huxley Memorial Lecture for 1945 on "The Ancient Oikoumenê as an Historic Culture Aggregate", a memorable development of some aspects of his interpretation of cultural diffusion through the Eurasian land mass from the earliest times to the present.

W. B. FAGG

\section{OBITUARIES}

Prof. G. N. Lewis, For.Mem.R.S.

By the death of Gilbert Newton Lewis in his seventy-first year the world has lost one of the greatest of its physical chemists. Since 1898, when he published his first paper wilh T. W. Richards on "Some Electrochemiffir The Thermochemical Relations of Zine and CadNium", until his last paper on."Paramagnetis of the Phosphorescent State" in 1945, he whote some hundred and sixty-five papers on many off Aches of physical chemistry.

Thpre are few branches of our science which 'G. N.' did not illumine by contributing something new and something fundamental to them. He was appreciated most widely abroad, not only for his concept of the static atom and the clear views on valency, notably the electron pair which that gave rise to, but also for his contributions to the thermodynamics and free energies of chemical substances and solutions, which introduced conceptions such as thermodynamic activity and fugacity now universally adopted. Many of the free-energy relationships were determined by means of electrode potentials-a field to which he devoted much attention. Lewis was the first (1933) to isolate deuterium, the heavy hydrogen isotope, to show its possibilities in the study of isotopic reactions, and to determine the physical properties of liquid and solid deuterium. His papers on acids and bases, on ultimate rational units and dimensional theory, give some indication of the wide interests of a gifted mind. During the last five years of his life he became deeply concerned with the problem of fluorescence, contributing some fifteen papers on this subject. His last papers, on phosphorescence and paramagnetism, were published last year.

The small volume printed in Berkeley to commemorate his seventieth birthday reveals how much America in its universities and industries is indebted to the school of which G. N. Lewis was the active and stimulating head. Among his many honours he received the Davy Medal of the Royal, Society and was an honorary fellow of the Royal Institution. Some of us at Cambridge remember the summer when he paid us a visit, memorable for the enthusiasm which he imparted to all, and to the endless source of wonder and interest to his children which the differences in the countryside of California and Cambridge provided.

Eric K. RIDEAL

\section{Prof. F. Broili}

Ferdinand Bgofin professor of palæontology and historical gedlats in the University of Munich, died on April 90 , aged seventy-two. He was a student of v. ZittA Rothpletz in Munich, visited the Pefpiand Texas in 1898 and there collected materials on hich, during the next ten years, he published a sorid of important papers on reptiles and amphibia. $\mathrm{He}$ then wrote on the Permian Brachiopods of Timor 